\title{
GANGGUAN BERBAHASA PADA ANAK USIA SEMBILAN TAHUN AKIBAT KELUMPUHAN PADA VELUM MULUT: PERSPEKTIF FONOLOGI
}

\section{Language Disorders in Nine Years Old Children Due To Public Overview Of The Oral Velum: Phonological Persepective}

\author{
Septara Utrujjah Dwy Putri \\ UIN Syarif Hidayatullah Jakarta \\ Septara.putri907@gmail.com
}

\begin{abstract}
Abstrak
Penelitian ini bertujuan untuk mengetahui gangguan berbahasa dari perspektif fonologi dalam hal pelafalan fonem, mana yang memiliki gangguan dan mana yang normal. Penelitian ini menggunakan pendekatan penelitian kualitatif. Objek penelitian ini berupa bunyi-bunyi fonem yang sulit dan tidak sulit diujarkan oleh penderita kelumpuhan langit-langit mulut atau sumbing langit-langit. Sumber data (informan) dalam penelitian ini adalah seorang anak penderita sumbing langit-langit berusia sembilan tahun. Penyediaan data menggunakan metode simak dan wawancara, teknik simak meliputi catat serta rekam. Berdasarkan hasil penelitian bahwa di beberapa fonem informan mengalami kesulitan dalam melafalkan bunyinya dan cenderung terdengar sengau, namun ada beberapa pula fonem yang terdengar jelas seperti orang normal. Kata Kunci: Gangguan berbahasa, Perspektif fonologi, Sembilan tahun.

\section{Abstract}

This study aims to determine language disorder from a phonological persepectve in terms if phoneme pronunciationm which ones have interference and which ones are normal. This study uses a qualitative research approach. The object of this research is phoneme sounds that are difficult and not difficult to pronounce by people with palate paralysis or cleft palate. The data source (informant) in this study was a child with cleft palate aged nine years. provision of data using observation and interview methods, listening techniques include note-taking and recording. Based on the result of the study, some phonemes, the informants had difficulty pronouncing the sounds and tended to sound nasal, but there were also some phonemes that sounded clear like normal people.

Keywords: Language disorders, Phonological perspective, nine years
\end{abstract}

\section{PENDAHULUAN}

Bahasa merupakan alat komunikasi antar manusia untuk melahirkan pikiran dan perasaan, lebih lanjut Yonohudiyono menjelaskan bahwa interaksi dan segala macam kegiatan dalam masyarakat akan lumpu tanpa bahasa, ini artinya bahasa merupakan pusat peradaban dari masyarakat. (Erviana, 2017: 1) Dengan bahasa pula fenomena dapat ditarik dari berbagai sisi, sisi-sisi itu berupa struktur bahasa, penggunaan bahasa, fungsi bahasa, pemrosesan bahasa, pembelajaran bahasam hingga pemerolehan bahasa yang tidak disadari oleh penggunanya. (Nuyani dan Dona, 2013) dan bahasa yang dihasilkan untuk berkomunikasi pastinya berbentuk bunyi-bunyi. Bunyi-bunyi ini nantinya disebut dengan bunyi bahasa yang dihasilkan karena adanya udara yang dihisap paru-paru dan dihembuskan secara bersama ketika bernafas. (Marsono, 2008) ketika proses ini udara mendapatkan hambatan di organ wicara sehingga meletupkan bunyi-bunyi bahasa yang dapat dimengerti oleh sesama manusia. 
Proses bahasa pada manusia merupakan proses yang sungguh rumit, Chaer menganalogikan ini seumpama proses pada komputer oleh sebab itu proses pemerolehan, pembelajaran, dan penggunaan bahasa yang tidak bisa disamakan antara manusia satu dengan mansuia yang lainnya dan harus kita aminkan pula tidak semua manusia bisa menghasilkan bunyi bahasa yang sempurna. Ketidaksempurnaan dalam pemrosesan berbahasa diakibatkan tidak terkoneksinya bagian-bagian yang berperan dalam berbicara, imbas dari tidak terkoneksinya bagian-bagian adalah gangguan pada manusia, dalam psikolinguistik terdapat disiplin ilmu yang menjelaskan dan berhubungan dengan gangguan berbahasa. Gangguan berbahasa dapat dipelajari dengan dua alasan mendasar. Pertama dengan memahami kesulitan penyadangan gangguan bahasa dalam bidang linguistik dan dengan membandingkannya dengan pemerolehan bahasa secara normal. Dan secara teoritis dengan mempelajari penyimpangan pemerolehan bahasa. (Field, 2003)

Secara umum gangguan berbahasa dapat dibagi menjadi dua, ada gangguan berbahasa karena faktor medis dan gangguan berbahasa karena faktor lingkungan sosial. Dan secara medikal ada tiga kelompok gangguan berbahasa (Chaer, 2009) gangguan tersebut antara lain, gangguan dalam berbicara, gangguan berbahasam dan gangguan dalam berpikir. Bentuk dan jenis dari gangguan berbicara ada banyak macamnya, salah satunya adalah kelumpuhan pada velum mulut atau istilah yang sering kita di dengar adalah sumbing langit-langit. Gangguan berbahasa jenis ini termasuk gangguan berbahasa secara biologis, artinya gangguan berbahasa akibat ketidaksempuarnaan organ bicara. Contoh lainnya yaitu yang dialami tunarungu dan tunanetra. Dalam (Chaer, 2003) berdasarkan mekanismenya, gangguan dalam berbicara dapat terjadi akibat kelainan pada paru-paru (pulmonal), pita suara (laring), pada lidah (lingual), serta pada rongga mulut dan kerongkongan (resonental). Pada kasus yang dilakukan penulis adalah kelumpuhan pada bagian resonental atau resonasi, akibatnya suara yang dihasilkan menjadi sengau. Rongga langit-langit itu tidak memberikan resonansi yang seharusnya sehingga suaranya menjadi bersengau. (Rohmani, 2017: 58)

Penderita sumbing langit-langit bisa terkena siapa saja, yang ada umumnya memang bawaan dari lahir. Penderita sumbing langit-langit akan menghasilkan suara yang tidak jelas seperti bindeng atau sengau (Supendi dan Setiadi, 2016: 105). Orang-orang yang mengalami kelumpuhan pada velum mulut selain suara terdengar sengau juga mengalami ketidakjelasan dalam mengucapkan fonem-fonem tertentu. Terutama fonem konsonan yang melibatkan bunyi letupan, seperti fonem /p/,/b/,/k/,/g/,/A/ (Verhaar, 2001: 14) oleh sebab itu penelitian mengenai sumbing langit-langit atau kelumpuhan pada velum mulut ini masih jarang ditemukan menjadi alasan yang kuat penulis untuk meneliti lebih lanjut.

Pada penelitian ini penulis menggunakan objek penelitian anak berusia 9 tahunyang bernama Azizah Nur Fadzlah. Azizah Nur Fadzal atau yang lebih sering dipanggil Hazah adalah anak ketiga dari tiga bersaudara. Hazah lahir di jambi tempat ia dan orang tuanya berdomisili saat ini. Latar belakang keluarga yang sederhana menjadikan Hazah anak yang ramah dan sopan dengan keistimewaannya. Seperti anak pada umumnya ia sekolah di sekolahan negeri dan memilki teman-teman yang secara artikulasi dalam berbicara berbeda dengannya. Hazah adalah anak yang aktif berbicara dan berinteraksi dengan orang-orang, bahkan tidak segan memanggil orang terlebih dahulu, artinya lingkungan tempat ia tumbuh, 
membrikan energy yang positif dan mendukungnya dan melihat sumbing langit-langit adalah bentuk keistimewaan pada diri Hazah, terlebih orang tuanya.

Peneliti tertarik dengan penelitian ini mengetahui gangguan berbahasa berupa kelumpuhan velum mulut atau sumbing langit-langit lunak, yang nantinya peneliti melihat pelafalan-pelafan fonem per silabel, mana saja kiranya bunyi yang mengalami ganguan dan mana yang tidak.

\section{METODE}

Metode yng dilakukan dalam penelitian ini adalah kualitatif. Sebagaimana yang diungkapkan oleh Bogdan dan Taylor bahwa metode penelitian deskriptif kualitatif adalah sebuah prosedur penelitian yng menghasilkan data deskriptif berupa kata-kata tertulis atau lisan dari orang-orang dan perilaku yang dapat diamati. (L.J Moleong, 2011:4).Teknik simak dan catat dilakukan oleh peneliti dibantu dengan rekaman yang sudah dilakuksn tempo hari. Rekaman sebagai sebuah sumber data yang diperoleh dari rekaman percakapan dengn anak usia 9 tahun yang bernama Azizah Nur Fadzlah. Ia bersejolah di SDN 120 Kota Jambi yang beralamat di Perumnas Aurduri, Kota Jambi. Teknik pengambilan data dilakukan dengan melakukan simak dan catat, yaitu berupa wawancara dan juga mencatat point-point penting dari ucapan si anak. Wawancara dilakukan tidak hanya satu kali, tetapi berkali-kali sehingga ditemukan data-data yang relevan untuk di analisis, Setelah melakukan proses wawancara dan juga perekaman maka hasil rekaman di simpan sebagai bukti penelitian dan sumber data.

\section{HASIL DAN PEMBAHASAN}

Vokal

Huruf vokal adalah bunyi bahasa yang dihasilkan dengan getaran pita suara tanpa adanya penyempitan dalam saluran suara di atas glottis (Yusuf, 1998 :179). Contohnya a,I,u,e,o. namun ketika huruf vokal ini dilafalkan oleh penderita sumbing langit-langit maka akan dideskripsikan sebagai berikut, dengan kode $\mathrm{N}$ untuk orang normal dan SL untuk sumbing langit:

1. Bunyi /a/

$\begin{array}{llll} & & \mathrm{N} & \mathrm{SL} \\ \text { Awal } & : \text { Aku } & {[\mathrm{aku}]} & {[\mathrm{a} \text { ?jo] }} \\ \text { Tengah } & : \text { Nama } & \text { [nama] } & \text { [na?ma] } \\ \text { Akhir } & : \text { Fadzla } & \text { [fazla] } & \text { [ma?zla] }\end{array}$

Data:

Peneliti : "Nama adek siapa?"

Anak : "Nama Aku Azizah Nur Fadzla"

Dari analisis di atas terdapat perubahan pada vokal /a/ yaitu menjadi sengau dan tidak begitu jeals, yang biasanya terjadi pada huru-huruf nasal. Perubahan ini dapat dilihat dari kata awal tengah dan akhir. 
2. Bunyi/i/

$\begin{array}{llll} & & \mathrm{N} & \mathrm{SL} \\ \text { Awal } & \text { : ibu } & \text { [ibuv] } & \text { [imuv] } \\ \text { Tengah } & \text { : hilang } & \text { [hilay] } & \text { [hi?lay] } \\ \text { Akhir } & \text { : hari } & \text { [hari] } & \text { [ali] }\end{array}$

Data:

Peneliti : "Tadi pada kakak sampai sini kenapa Haza nangis"

Anak : "Ibu, ga mau kasih uang jajan, katanya Haza banyak jajan setiap hari, biarin aja uang ibu hilang"

Sama seperti bunyi /a/ bunyi/i/ mengalami perubahan menjadi nasal pada awal, tengah dan akhir kata.

3. Bunyi $/ \mathrm{u} /$

$\begin{array}{llll} & & \mathrm{N} & \mathrm{SL} \\ \text { Awal } & \text { : umur } & \text { [Umur] } & \text { [U?mul] } \\ \text { Tengah } & \text { : tahun } & \text { [tahun] } & \text { [nahun] } \\ \text { Akhir } & : \text { aku } & {[\text { aku] }} & \text { [a?yo] }\end{array}$

Data :

Peneliti :"Umur kamu sekrarang berapa sih?"

Anak : "Umur aku sekarang Sembilan tahun"

Terjadi perubahan pada fonem $/ \mathrm{u} /$ menjadi bunyi nasal $[\mathrm{u}]$.

4. Bunyi /e/

$\begin{array}{llll} & & \mathrm{N} & \mathrm{SL} \\ \text { Awal } & : \text { ekor } & {[\varepsilon \mathrm{kOr}]} & {[\varepsilon \text { ?̧Ol] }} \\ \text { Tengah } & : \text { nenek } & {[\mathrm{n} \varepsilon \mathrm{n} \varepsilon \text { ? }]} & {[\text { nene? }]} \\ \text { Akhir } & \text { : sore } & {[\mathrm{sOre}]} & {[\mathrm{hOle}]}\end{array}$

Data

: "Kakak, orang punya dua ekor ikan cupang"

$\begin{array}{ll}\text { Anak } & \text { : "Kakak, orang puny } \\ \text { Peneliti: } & \text { "Wah beli di mana?" }\end{array}$

Anak : "Engga beli, dikasih nenek kemarin sore" "suka aku gabungin, yang satunya jago berantem"

Dari analisis di atas pada bunyi /e/ ada gangguan berupa suara sengau pada saat pelafalan. Yaitu berubah menjadi vokal nasal. Perubahan tersebut terjadi di awal, tengah dan akhir kata.

5. Bunyi /o/

$\begin{array}{llll} & & \mathrm{N} & \mathrm{SL} \\ \text { Awal } & \text { : orang } & {[\text { Oran] }} & \text { [o ?la j] } \\ \text { Tengah } & \text { : sore } & \text { [sOre] } & \text { [hOle] } \\ \text { Akhir } & \text { : jago } & \text { [jagO] } & \text { [na?jo] }\end{array}$

Data: (sumber data yang sama dengan pelafalan bunyi huruf /e/) 
Dari analisis di atas tidak ada perubahan suara pada saat pelafalan bunyi baik di awal, tengah maupun akhir.

\section{Konsonan}

Konsonan adalah bunyi bahasa yang dihasilkan dengan mengahambat aliran udara pada salah satu tempat di saluran udara. Contoh: b,c,f,g,h,j,k,l, dan seterusnya. (Yusuf, 1998: 159). Namun ketika konsonan-konsonan itu dilafalkan oleh sumbing langit-langit maka akan terlihat perbedaanya melalui deskripsi berikut:

1. Bunyi /b/

\begin{tabular}{|c|c|c|c|}
\hline $\mathrm{Au}$ & $: \mathrm{b}$ & $\begin{array}{l}\mathrm{N} \\
\text { [bəlil }\end{array}$ & $\begin{array}{l}\text { SL } \\
\text { [mə?i] }\end{array}$ \\
\hline Tengah & : bebek & [bebck] & {$[\mathrm{m} \varepsilon \mathrm{m} \varepsilon ?]$} \\
\hline Akhir & : kebab & [kəbab] & [ฤəmab] \\
\hline \multicolumn{4}{|l|}{ Data: } \\
\hline Anak & \multicolumn{3}{|c|}{ : "kak aku lapar, mau beli kebab' } \\
\hline Peneliti & \multicolumn{3}{|c|}{ : "emang jualan kebab di mana di sini?" } \\
\hline Anak & \multicolumn{3}{|c|}{ : "itu yang deket warung bebek" } \\
\hline
\end{tabular}

Dari analisis bunyi /b/ di atas. Diperoleh hasil bahwa fonem /b/ berubah bunyi menjadi nasal / $\mathrm{m} /$ di awal dan tengah kata. Sedangkan di akhir kata fonem /b/ tidak berubah. Jadi penyandang lumpuh velum mulut mampu menyebutkan kata-kata berakhiran fonem $/ \mathrm{b} /$.

2. Bunyi /c/

$\begin{array}{llll} & & \mathrm{N} & \mathrm{SL} \\ \text { Awal } & \text { : cumi-cumi } & \text { [cUmi-cUmi] } & \text { [nu?mi- nu?mi] } \\ \text { Tengah } & : \text { cacing } & \text { [cacin] } & \text { [na?nin] } \\ \text { Akhir } & :- & - & -\end{array}$

Data:

Peneliti : "Hazah tadi di rumah makan apa?"

Anak : "Tadi siang makan nasi pake cumi-cumi sambal"

Peneliti : "Hewan yang Hazah takuti apa?"

Anak : : "Aku ga takut hewan sih Kak, Cuma aku jijik, jijik sama cacing"

Pada fonem bunyi /c/ terdapat perubahan fonem dari /c/ menjadi bunyi nasal [ $\eta$ di awal dan di tengah kata, tidak di temukannya di akhir kata sebab dari data percakapan tidak ada kata yang berakhiran bunyi [c].

3. Bunyi /d/

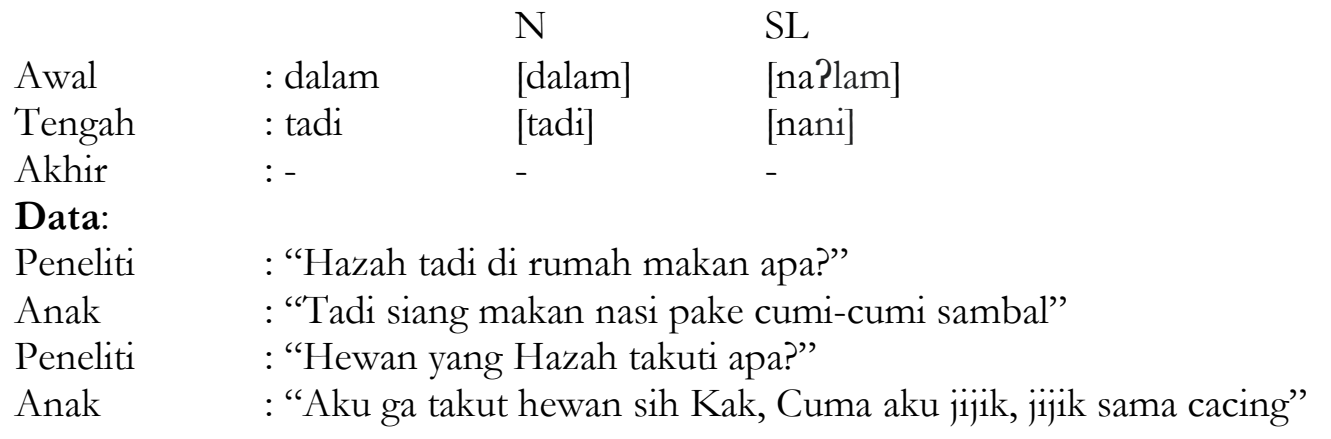


Peneliti : "Kok bisa jijik?”

Anak : "Iya pas itu pernah jatuh gara-gara cacing, lukanya dalam banget"

Dari data analisis di atas ditemukan bahwa bunyi /d/ mengalami perubahan di awal dan di tengah kata menjadi bunyi $/ \mathrm{n} /$.

4. Bunyi /f/

$\begin{array}{llll} & & \mathrm{N} & \mathrm{SL} \\ \text { Awal } & : \text { foto } & {[\mathrm{fOtO}]} & {[\text { ho?to] }} \\ \text { Tengah } & :- & - & - \\ \text { Akhir } & :- & - & -\end{array}$

Data:

Anak : "Kak boleh pinjam hape ga, mau foto"

Peneliti: "Boleh-boleh nih"

Bunyi /f/ bagi penderita sumbing langit-langit lunak atau velum mulut terjadi perubahan bunyi menjadi /h/ di awal kalimat. Untuk tengah dan akhir kalimat karena dari data percakapan tidak ditemukan bukti-bukti terkait.

5. Bunyi /g/

$\begin{array}{llll} & & \mathrm{N} & \mathrm{SL} \\ \text { Awal } & \text { : gabungin } & \text { [gabUnin] } & \text { [ๆ?munin] } \\ \text { Tengah } & : \text { jago } & \text { [jagO } & \text { [na?jo] } \\ \text { Akhir } & :- & - & -\end{array}$

Data:

Anak : "Kakak, orang punya dua ekor ikan cupang"

Peneliti : "Wah beli di mana?"

Anak : "Engga beli, dikasih nenek kemarin sore" "suka aku gabungin, yang satunya jago berantem"

Dari data analisis di atas bahwa bunyi /g/ di awal maupun di tengah kata mengalami perubahan menjadi bunyi [ $\mathrm{y}]$.

6. Bunyi /h/

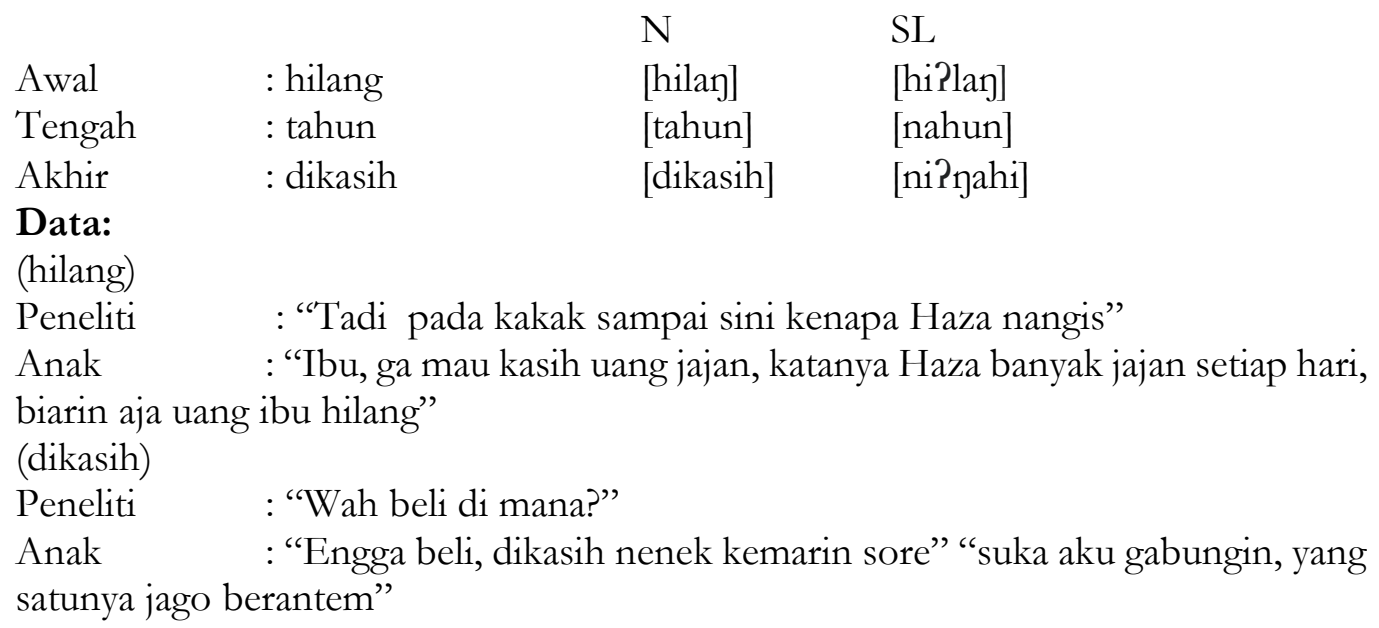


Dari data analisis di atas pada fonem /h/ ada perbedaan dari data sebelumnya, yaitu orang-orang sumbing langit-langit sangat jelas dalam melafalkan bunyi fonem $/ \mathrm{h} / \mathrm{di}$ awal, tengah maupun akhir.

7. Bunyi /j/

\begin{tabular}{|c|c|c|c|}
\hline & & $\mathrm{N}$ & SL \\
\hline Awal & : jatuh & [jatuh] & [na?nuh] \\
\hline Tengah & : jijik & [jiji?] & [ni?ni?] \\
\hline Akhir & $:-$ & - & - \\
\hline Data: & & & \\
\hline Peneliti & : "Hew & takuti ap & \\
\hline Anak & : “Aku & sih Kak & aku jijik, jijik sama cacing” \\
\hline Peneliti & : "Kok & & \\
\hline Anak & : "Iya p & tuh gara & cing, lukanya dalam banget" \\
\hline
\end{tabular}

Pada fonem $/ \mathrm{j} /$ terjadi perubahan bunyi menjadi bunyi $/ \mathrm{n} /$ di awal dan di tengah kata.

8. Bunyi $/ \mathrm{k} /$

\begin{tabular}{|c|c|c|c|}
\hline Awal & : kakak & $\begin{array}{l}\mathrm{N} \\
\text { [kaka? }\end{array}$ & $\begin{array}{l}\text { SL } \\
\text { [nana?] }\end{array}$ \\
\hline Tengah & : takut & [takut] & [na?yut] \\
\hline Akhir & : nenek & [nعn\&?] & 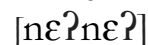 \\
\hline
\end{tabular}

Data:

(kakak dan nenek)

Anak : :Kakak, orang punya dua ekor ikan cupang"

Peneliti : "Wah beli di mana?"

Anak : "Engga beli, dikasih nenek kemarin sore" "suka aku gabungin, yang satunya jago berantem"

(takut)

Peneliti : "Hewan yang Hazah takuti apa?"

Anak : :Aku ga takut hewan sih Kak, cuma aku jijik, jijik sama cacing”

Dari data analisis fonem $/ \mathrm{k}$ / bagi orang sumbing langit-langit mengalami perubahan pelafalan jika bunyi tersebut di awal dan di tengah kata seperti contoh di atas menjadi bunyi [y], namun mereka akan jelas dan seperti orang normal saat berbicara dengan fonem $/ \mathrm{k} /$ ketika bunyi tersebut di akhir kata.

9. Bunyi /1/

$\begin{array}{llll} & & \mathrm{N} & \mathrm{SL} \\ \text { Awal } & \text { : luka } & {[\mathrm{Uka}]} & {[\text { lurka] }} \\ \text { Tengah } & \text { : beli } & {[\text { boli] }} & \text { [məli] } \\ \text { Akhir } & \text { : adil } & \text { [adil] } & \text { [anil] }\end{array}$

Data:

Peneliti: "Ini buat kamu dua, buat kakak tiga yaa"

Anak : "ih ga adil, kakak!" 
Fonem yang berbunyi [1] tidak mengalami perubahan di awal, tengah maupun akhir. Sumbing langit-langit tidak menghambat pelafalan fonem /1/.

10. Bunyi $/ \mathrm{m} /$

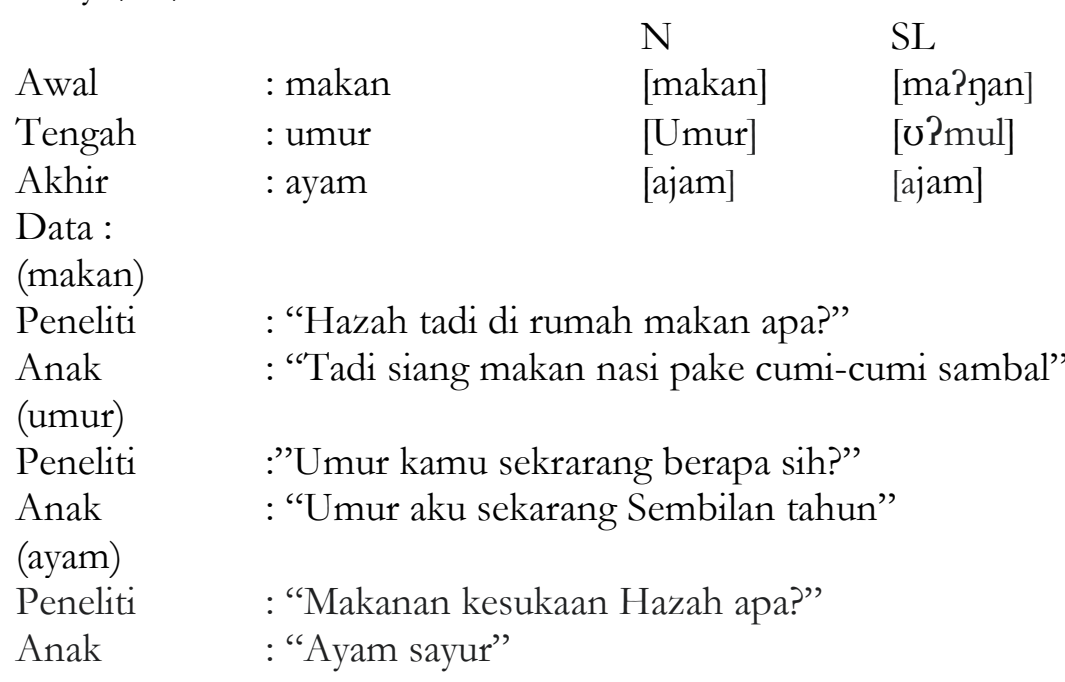

Dari data analisis di atas, orang-orang sumbing langit-langit tidak mengalami gangguan saat pelafalan bunyi /m/ baik itu di awal, tengah maupun akhir kata.

11. Bunyi /n/

\begin{tabular}{llll} 
& & $\mathrm{N}$ & SL \\
Awal & : nasi & [nasi] & [nahi] \\
Tengah & : pernah & [pərnah] & [məlnah] \\
$\begin{array}{l}\text { Akhir } \\
\text { Data: }\end{array}$ & : hewan & [həoan] & [həvan] \\
(nasi) & \multicolumn{3}{l}{} \\
$\begin{array}{l}\text { Peneliti } \\
\text { Anak }\end{array}$ & : "Hazah tadi di rumah makan apa?" \\
(pernah dan hewan) & \\
Data: &
\end{tabular}

Peneliti : "Hewan yang Hazah takuti apa?"

Anak : "Aku ga takut hewan sih Kak, Cuma aku jijik, jijik sama cacing"

Peneliti : "Kok bisa jijik?"

Anak : "Iya pas itu pernah jatuh gara-gara cacing, lukanya dalam banget"

Dari data analisis di atas, orang-orang sumbing langit-langit tidak mengalami gangguan saat pelafalan bunyi / $\mathrm{n} /$ baik itu di awal, tengah maupun akhir kata.

12. Bunyi /p/

$\begin{array}{llll} & \mathrm{N} & \mathrm{SL} \\ \text { Awal } & \text { : pake } & {[\text { pake] }} & \text { [mane?] }\end{array}$




$\begin{array}{llll}\text { Tengah } & \text { : lapar } & \text { [lapar } & \text { [la?mal] } \\ \text { Akhir } & \text { : setiap } & \text { [sətiap] } & \text { [həniap] }\end{array}$

Data:

(pake)

Peneliti : "Hazah tadi di rumah makan apa?"

Anak : "Tadi siang makan nasi pake cumi-cumi sambal"

(lapar)

Anak : "kak aku lapar, mau beli kebab"

Peneliti : "emang jualan kebab di mana di sini?"

Anak : "itu yang deket warung bebek"

(setiap)

Peneliti : "Tadi pada kakak sampai sini kenapa Haza nangis"

Anak : "Ibu, ga mau kasih uang jajan, katanya Haza banyak jajan setiap hari, biarin aja uang ibu hilang"

Dari data analisis di atas orang yang mengalami sumbing langit-langit mengalami gangguan saat mengucapkan fonem / $/$ / berubah menjadi bunyi [m] di awal dan tengah kata. Namun tidak mengalami gangguan saat fonem tersebut di akhir kata.

13. Bunyi /r/

$\begin{array}{llll} & & \mathrm{N} & \text { SL } \\ \text { Awal } & \text { : rabu } & {[\text { rabU] }} & \text { [lamu] } \\ \text { Tengah } & \text { : warung } & \text { [varuy] } & \text { [waluy] } \\ \text { Akhir } & \text { : lapar } & \text { [lapar] } & \text { [larpal] } \\ \text { Data: } & & \\ \text { (rabu) } & & \\ \text { Peneliti } & \text { : "Kapan Hazah ke rumah sakit?" } & \\ \text { Anak } & \text { : "Hari Rabu kalo ga salah" } & \\ \text { (warung dan lapar) } & & \\ \text { Anak } & : \text { "kak aku lapar, mau beli kebab" } \\ \text { Peneliti } & : \text { "emang jualan kebab di mana di sini?" } \\ \text { Anak } & : \text { "itu yang deket warung bebek" } & \end{array}$

Dari data analisis di atas fonem $/ \mathrm{r} /$ mengalami gangguan di awal, tengah dan di akhir kata menjadi bunyi [1].

14. Bunyi /s/

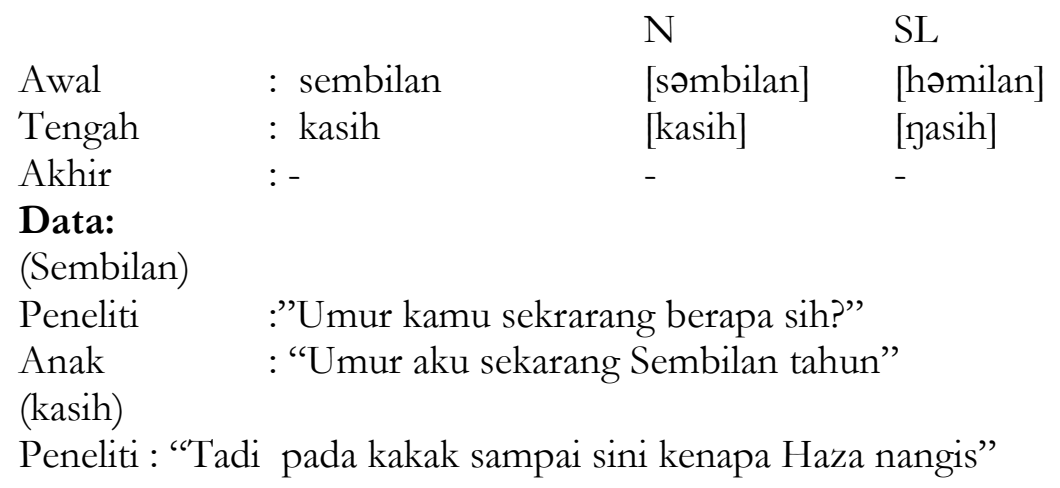


Anak : "Ibu, ga mau kasih uang jajan, katanya Haza banyak jajan setiap hari, biarin aja uang ibu hilang"

Dari data analisis di atas pada fonem / s / terdapat perubahan di awal dan tengah kata menjadi bunyi $[\mathrm{h}]$.

15. Bunyi /t/

\begin{tabular}{|c|c|c|c|}
\hline \\
\hline & & $\begin{array}{l}\mathrm{N} \\
\text { [tadil }\end{array}$ & $\begin{array}{l}\text { SL } \\
\text { [na?dil }\end{array}$ \\
\hline Tengah & : jatuh & [jatuh] & [nanuh] \\
\hline Akhir & : takut & [takut] & [na?yut] \\
\hline Data: & & & \\
\hline Peneliti & : “Hewa & takuti ap & \\
\hline Anak & : "Aku g & sih $\mathrm{Kak}$ & aku jijik, jijik sama cacing” \\
\hline Peneliti & : "Kok b & & \\
\hline Anak & : "Iya pa & ituh gara & acing, lukanya dalam banget" \\
\hline
\end{tabular}

Dari data analisis di atass fonem / $\mathrm{t} /$ mengalami perubahan di awal dan tengah kata menjadi bunyi [n] namun tidak mengalami perubahan di akhir kata.

16. Bunyi /o/

$\begin{array}{llll} & & \mathrm{N} & \mathrm{SL} \\ \text { Awal } & : \text { warung } & \text { [varun] } & \text { [varruy] } \\ \text { Tengah } & : \text { hewan } & \text { [hevan] } & \text { [hePvan] } \\ \text { Akhir } & :- & - & -\end{array}$

Data:

(warung)

Anak : "kak aku lapar, mau beli kebab"

Peneliti : "emang jualan kebab di mana di sini?"

Anak : "itu yang deket warung bebek"

(hewan)

Data yang sama dengan bunyi / $\mathrm{t} /$ Pada fonem [v] tidak mengalami perubahan di awal dan tengah kata.

\section{SIMPULAN}

Kelainan yang di alami penderita sumbing langit-langit menyebabkan berkurangnya fungsi pada artikulator. Sumbing langit-langiti yang merupakan kelumpuhan bawaan dari lahir rata-rata terjadi daerah mulut sampai dengan langit-langit, berdasarkan sumber penelitian bahwa anak tersebut mengalami kelumpuhan pada velum mulut yaitu sumbing langit-langit lunak. Kendala yang dialami mengakibatkan bunyi-bunyi bahasa yang dihasilkan tidak terdengar begitu jelas.

Berdasarkan pembahasan di atas bunyi-bunyi vokal mengalami gangguan karena terdaat celah pada langit-langit mulut yang mana tempat fonem-fonem ini keluar. Lafa-lafal vokal a, i, u, e dan o menjadi vokal nasal [a, i, u, e dan o]. 
Sedangkan fonem-fonem konsonan sangat variatif seperti fonem-fonem berikut yang mengalami perubahan da nada yang tidak mengalami perubahan.

Fonem konsonan yang mengalami perubahan, antara lain:

1. Fonem /b/ menjadi bunyi [m] di awal dan tengah kata

2. Fonem /c/ menjadi bunyi [n] di awal dan tengah kata

3. Fonem /d/ menjadi bunyi [n] di awal dan tengah kata

4. Fonem /f/ menjadi bunyi [h] di awal kata

5. Fonem $/ \mathrm{g} /$ menjadi bunyi [ $\mathrm{g}]$ di awal dan tengah kata

6. Fonem $/ \mathrm{j} /$ menjadi bunyi $[n]$ di awal dan tengah kata

7. Fonem $/ \mathrm{k} /$ menjadi bunyi [ $\mathrm{r}$ ] di awal dan tengah kata

8. Fonem $/ \mathrm{p} /$ menjadi bunyi $[\mathrm{m}]$ di awal dan tengah kata

9. Fonem $/ \mathrm{r} /$ menjadi bunyi [1] di awal tengah dan akhir kata

10. Fonem /s/ menjadi bunyi $[\mathrm{h}]$ di awal dan tengah kata

11. Fonem /t/ menjadi bunyi [n] di awal dan tengah kata

Fonem konsonan yang tidak mengalami perubahan, antara lain:

1. Fonem $/ \mathrm{b} /$ di akhir kata

2. Fonem $/ \mathrm{h} /$ di awal, tengah, dan akhir kata.

3. Fonem $/ \mathrm{k} /$ di akhir kata

4. Fonem $/ 1 /$ di awal, tengah dan akhir kata

5. Fonem $\mathrm{m} / \mathrm{di}$ awal, tengah dan akhir kata

6. Fonem $/ \mathrm{n} /$ di awal, tengah dan akhir kata

7. Fonem $/ \mathrm{p} /$ di akhir kata

8. Fonem $/ \mathrm{t} / \mathrm{di}$ akhir kata

9. Fonem $/ v /$ di awal dan tengah kata

Dari rangkuman analisis di atas artinya penderita kelumpuhan velum mulut kesulitan dalam melafalkan huruf-huruf vokal sebab terdengar lebih sengau. Kemudian untuk fonemfonem konsonan terdapat kesamaan di beberapa fonem, seperti fonem /b/ dan /p/ terdengar sama menjadi bunyi $[\mathrm{m}]$ jadi sulit membedakan penafsiran dua fonem tersebut. Selain itu hal yang serupa pada fonem /c/ dan / $\mathrm{j} /$ dilafalkan sama menjadi bunyi [ $\eta$ ], pada fonem /d/ dan / $/$ / sulit pula melihat perbedaanya sebab dilafalkan dengan bunyi yang sama yaitu menjadi [n], pada fonem / f/ dan /s/ menjadi bunyi yang sama yaitu bunyi [h], dan pada fonem $/ \mathrm{g} / \mathrm{dan} / \mathrm{k} /$ yang memilki kemiripan dan pelafalan menjadi bunyi $/ \mathrm{y} /$.

\section{DAFTAR PUSTAKA}

Erviana, Yurita. 2017. Strategi Guru dalam Menangani Gangguan Berbahasa Khusu serta Implikasinya terhadap Keterampilan Sosial Anak Usia Dini. Tesis UIN Sunan Kalijaga. Di akses pada 9 Desember 2020. Tersedia dihttp://digilib.uin-suka.ac.id/27898/1/ 1520431009_BAB-I_IV-atauV_DAFTAR-PUSTAKA.pdf

Nuryani dan Dona Aji Karunia Putra/ (2013). Psikolinguistik. Tangerang Selatan: Mazhab Ciputat. 
Indah, Rohmani Nur. 2017. Gangguan Berbahasa Kajian Pengantar. Ebook. Malang: UIN Malkiki Press.

Chaer, Abdul. 2009. Pskiolinguistik Kajian Teoritik. Jakarta: Rineka Cipta

Supendi, D.A. dan Setiadi, D. 2016. Analisis Kasus dan Penyebab Gangguan Berbahasa (language Disorder). Universitas Negeri Surabaya, Indonesia, Indonesia.

Verhaar. 2001. Asas-asas Linguistik Umum. Yogyakarta: Gajah Mada University Press.

Moleong, L.J. 2002. Metodologi Penelitian Kualitatif. Bandung: PT REmaja Rosda Karya.

Yusuf, Suhendar. (1998). Fonetik dan Fonologi. Jakarta: Gramedia Utama.

Field, J. (2003). Psycholinguistics; A Resource Book for Students, Routledge, Routledge English Language Introductions. McGill University. 